\title{
Identification of proteins that can participate in the recruitment of Ttk69 to genomic sites of Drosophila melanogaster
}

\author{
I.S. Osadchiy, T.N. Fedorova, P.G. Georgiev, O.G. Maksimenko@
}

Institute of Gene Biology, RAS, Moscow, Russia

(). e-mail: maksog@mail.ru

\begin{abstract}
The proteins with the BTB domain play an important role in the processes of activation and repression of transcription. Interestingly, BTB-containing proteins are widely distributed only among higher eukaryotes. Many BTB-containing proteins are transcriptional factors involved in a wide range of developmental processes. One of the key regulators of early development is the BTB-containing protein Ttk (tramtrack), which is able to interact with the Drosophila nucleosome remodeling and histone deacetylation (dNuRD) complex. Ttk69 directly interacts with two protein components of the dNuRD complex, $\mathrm{dMi}-2$ and MEP1. It can be assumed that Ttk69 represses some target genes by remodeling chromatin structure through the recruitment of the dNuRD complex. However, it is still unknown what provides for specific recruitment of Ttk to chromatin in the process of negative/positive regulation of a target gene expression. Although Ttk69 has DNA-binding activity, no extended specific motif has been identified. The purpose of this study was to find proteins that can participate in the recruitment of Ttk to regulatory elements. To identify Ttk partner proteins, screening in the yeast two-hybrid system was performed against a collection of proteins with clusters of $\mathrm{C} 2 \mathrm{H} 2$ domains, which bind effectively and specifically to sites on chromatin. As a results, the CG10321 and CG1792 proteins were identified as potential DNA-binding partners of Ttk. We suppose that the CG10321 and CG1792 proteins provide specificity for the recruitment of Ttk and, as a result, of the NuRD-complex to the genome regulatory elements. We found that the Ttk protein is able to interact with the MEP1 and $\mathrm{ZnF}$ proteins at once.

Key words: Drosophila; protein-protein interaction; gene regulation; transcription factor; tramtrack.

For citation: Osadchiy I.S., Fedorova T.N., Georgiev P.G., Maksimenko O.G. Identification of proteins that can participate in the recruitment of Ttk69 to genomic sites of Drosophila melanogaster. Vavilovskii Zhurnal Genetiki i Selektsii = Vavilov Journal of Genetics and Breeding. 2019;23(2):180-183. DOI 10.18699/VJ19.479
\end{abstract}

\section{Идентификация белков, участвующих в привлечении белка Ttk69 к геномным сайтам у Drosophila melanogaster}

\author{
И.С. Осадчий, Т.Н. ФеАорова, П.Г. Георгиев, О.Г. Максименко ®
}

Институт биологии гена Российской академии наук, Москва, Россия

هe-mail: maksog@mail.ru

\begin{abstract}
Белки, имеющие в своем составе ВТВ-домены, играют важную роль в процессах активации и репрессии транскрипции. Белки, содержащие ВТВ-домены, широко распространены только среди высших эукариот. Многие из таких белков являются транскрипционными факторами, принимающими участие в процессах развития организма. Один из ключевых регуляторов процессов раннего развития - BTB-содержащий белок Ttk (tramtrack), способный взаимодействовать с комплексом ремоделирования нуклеосом и деацетилирования гистонов (dNuRD) дрозофилы. Белок Ttk69 способен напрямую взаимодействовать с двумя белками комплекса dNuRD complex, dMi-2 и MEP1. Можно предположить, что Ttk69 репрессирует мишеневые гены путем ремоделирования хроматина через привлечение комплекса dNuRD. Однако до сих пор неизвестно, что обеспечивает специфичность рекрутирования Ttk на хроматин в процессе негативной/позитивной регуляции генной экспрессии. Несмотря на то что Ttk69 обладает ДНК-связывающей активностью, протяженных специфичных мотивов связывания для него найдено не было. Целью данного исследования был поиск белков, которые могут участвовать в привлечении Ttk к геномным регуляторным элементам. Для поиска белков-партнеров Ttk был проведен скрининг в дрожжевой двугибридной системе против коллекции белков с кластерами доменов «цинковые пальцы» $\mathrm{C2H2-типа,} \mathrm{способных} \mathrm{эффективно} \mathrm{и} \mathrm{специфично} \mathrm{свя-}$ зываться с сайтами в хроматине. В результате два белка, CG10321 и CG1792, были описаны в качестве потенциальных ДНК-связывающих партнеров Ttk. Мы предполагаем, что CG10321 и CG1792 обеспечивают специфичность посадки Ttk на сайты и, как следствие, привлечение NuRD-комплекса к геномным регуляторным элементам. Мы обнаружили также, что белок Ttk может одновременно взаимодействовать с MEP1 и ZnF-белками.

Ключевые слова: дрозофила; белок-белковое взаимодействие; генная регуляция; транскрипционный фактор;
\end{abstract} tramtrack.

\section{Introduction}

The genome of higher eukaryotes is a complex, but at the same time flexible and tightly regulated system. The spatial and temporal specificity of gene activation or repression is realized in different ways. It is possible that proteins with the BTB domain play an important role in the processes of activation and repression of transcription. Interestingly, BTBcontaining proteins are widely distributed only among higher 
eukaryotes. Thus, 85 BTB proteins are known in Drosophila melanogaster, and 183 BTB proteins in Homo sapiens. The BTB/POZ (broad complex, Tramtrack, bric-a-brac/Pox virus and zinc finger) is an evolutionarily conserved protein-protein interaction domain. Most of the BTB domains are capable of forming multimers. Many BTB-containing proteins are transcriptional factors involved in a wide range of developmental processes. A special place among them is occupied by transcription factors that bind DNA using "zinc fingers" (BTB-ZF). Fifteen such proteins were found in Drosophila, and 43 , in humans. All known BTB-ZF proteins are involved in the regulation of transcription, in particular in the action of enhancers, promoters and insulators (Stogios et al., 2005; Perez-Torrado et al., 2006). Typically, the BTB domain is located at the N-terminus of a protein, while closer to the $\mathrm{C}$-terminus are zinc fingers of C2H2-type (ZF), which are involved in binding to DNA and interaction with other proteins. These proteins are often involved in the regulation of transcription and the organization of enhancer-promoter interactions (e. g., PLZF, Bcl6, GAF, Mod (mdg4), Ttk). The significance of the BTB domain in gene regulation has not been revealed. However, the BTB domain is involved in interactions with a number of proteins. In the case of Bcl6 and PLZF, the BTB domain directly interacts with the corepressors BcoR, N-CoR (SMRT), mSin3A (Melnick et al., 2002) to form a transcriptional repressor complex that includes the HDAC-1 histone deacetylase. In addition to interacting with corepressors, some BTB domains (GAF, bric-a-brac), in contrast, are associated with the TAFII155 transcription activator (Pointud et al., 2001; Chopra et al., 2008). The BTB domain of the Kaiso transcription factor is able to interact with the $\mathrm{C}$-terminal domain of the human CTCF protein, which weakens the insulator activity of the latter (Defossez et al., 2005).

One of the key regulators of early development is the BTBcontaining protein Ttk, which occurs in two isoforms, Ttk69 and Ttk88. These isoforms share the same BTB-domain but possess alternative sets of $\mathrm{Zn}$ fingers. Ttk69 is a repressor of tailless expression (Chen et al., 2002) and is a master repressor of enteroendocrine cell specification of Drosophila intestinal stem cell lineages (Wang et al., 2015). Also, Ttk69 regulates Drosophila oogenesis through selective and negative regulation of gene expression in follicle and germline cells (Boyle, Berg, 2009; Peters et al., 2013) and participates in photoreceptor development (Lai, Li, 1999). The BTB domain of Ttk69 genetically interacts with the transcriptional corepressor dCtBP (Drosophila homolog of human C-terminal-binding protein), which might be an interacting partner of Ttk69 for the control of cell fate decision and cellular differentiation (Wen et al., 2000). In addition, it was demonstrated that the Pits protein is able to interact with the BTB domain of Ttk69 and the Sin3A corepressor (Liaw, 2016). Moreover, Ttk69 directly interacts with two protein components of the Drosophila nucleosome remodeling and histone deacetylation (dNuRD) complex, dMi-2 (Murawsky et al., 2001) and MEP1 (Reddy et al., 2010). It can be assumed that Ttk69 represses some target genes by remodeling chromatin structure through the recruitment of the dNuRD complex.

Although Ttk has DNA-binding activity, no extended specific motif has been identified (Chen et al., 2002; Kulakovskiy, Makeev, 2009). Moreover, it was shown that Ttk69-mediated repression of GAGA-depended promoters occurs in the absence of Ttk69 binding to DNA (Pagans et al., 2004). These results, together with the detected interactions of Ttk69 with $\mathrm{dCtBP}$ and $\mathrm{dMi} 2$, suggest that depending on the promoter and the developmental stage, Ttk69 might repress transcription through different mechanisms (Pagans et al., 2004). However, it is still unknown what provides for specific recruitment of Ttk to chromatin in the process of negative/positive regulation of target gene expression.

The purpose of this study was to find proteins that can participate in the recruitment of Ttk69 to regulatory elements. To identify Ttk69 partner proteins, screening in the yeast twohybrid system was performed against a collection of proteins with clusters of $\mathrm{C} 2 \mathrm{H} 2$ domains, which bind effectively and specifically to sites on chromatin.

\section{Materials and methods}

Fusion proteins were cloned into vectors pGBT9 and pGAD424 from Clontech and verified by sequencing. Ttk69 (and deletion derivatives) were expressed in fusion with the Gal4 DNA binding domain (DBD) along with ZnF proteins (and deletion derivatives) fused to the Gal4 activation domain (AD) in a pairwise manner. The yeast two-hybrid assay was carried out using the yeast strain pJ69-4A (MATa trp1-901 leu2-3,112 ura3-52 his3-200 gal4 $\Delta$ gal80 $\Delta$ GAL2-ADE2 LYS2::GAL1-HIS3 met2::GAL7-lacZ), with plasmids and protocols from Clontech. For growth assays, plasmids were transformed into yeast strain pJ69-4A by the lithium acetate method, as described by the manufacturer with some modifications. All cells were grown at $30{ }^{\circ} \mathrm{C}$ in an orbital shaker at 250-300 rpm. Yeast colonies were transferred into a $15 \mathrm{~mL}$ culture tube with 6-7 mL of YPDA medium and grown for one day. The culture was 10 -fold diluted in a $0.5 \mathrm{~L}$ culture flask with YPDA medium and cultivated for $3 \mathrm{~h}$. Aliquots of $1.5 \mathrm{~mL}$ of cell suspension were pelleted by centrifugation at $4000 \mathrm{~g}$ for $10 \mathrm{~s}$, and the supernatant was removed. Pelleted cells were resuspended in $1 \mathrm{~mL}$ of $0.1 \mathrm{M} \mathrm{LiAcO}$, incubated for $30 \mathrm{~min}$ and pelleted as above. To the pellet, $240 \mu \mathrm{L} 50 \%$ (v/v) PEG $3380,36 \mu \mathrm{L}$ of $1 \mathrm{M} \mathrm{LiAcO}$, and $50 \mu \mathrm{L}$ of a mixture of two plasmids (the amount of each plasmid in a mixture of 400 $800 \mathrm{ng}$ ) was added sequentially and the cells were suspended to homogeneity. The tube was incubated at $30^{\circ} \mathrm{C}$ for $30 \mathrm{~min}$, then at $42{ }^{\circ} \mathrm{C}$ for $5 \mathrm{~min}$ and then placed on ice for 1-2 min. Cells were pelleted at $4000 \mathrm{~g}$ for 15-20 s and resuspended in $100 \mu \mathrm{L}$ of sterile ddH2O. The resuspended cells were plated on selective medium lacking Leu and Trp ("medium-2"). The plates were incubated at $30^{\circ} \mathrm{C}$ for $2-3$ days. Afterwards, the colonies were streaked out on plates on selective medium lacking either Leu, Trp and His ("medium-3"), or lacking adenine in addition to the three amino acids ("medium-4"), or lacking the three amino acids but containing $5 \mathrm{mM} 3$-amino-1,2,4triazole ("medium-3+5 mM 3AT"). The plates were incubated at $30{ }^{\circ} \mathrm{C}$ for 3-4 days and growth was assessed. Each assay was prepared as three independent biological replicates with three technical repeats.

\section{Results}

To identify new DNA-binding factors that might directly interact with Ttk, we performed a yeast two-hybrid assay against a collection of $\mathrm{ZnF}$ proteins. Ttk was expressed in 
fusion with a Gal4 DNA binding domain (DBD) along with $\mathrm{ZnF}$ proteins fused to the Gal4 activation domain (AD). Being co-expressed in yeast, the two associating proteins reconstitute the function of the transcription factor GAL4 that activates the his 3 gene in the yeast strain pJ69-4A, which is an auxotroph for histidine (Fig. 1,a). Yeasts with interacting DBD and AD fusion proteins can grow on plates lacking histidine, leucine and tryptophan. The assay revealed interaction of Ttk69 with CG10321 and CG1792. We also confirmed the previously described interaction of the Ttk69 protein with MEP1 (see Fig. 1,b)

Presumably, the CG10321 and CG1792 proteins provide specificity for the DNA-binding of Ttk69 and, as a result, the recruiting of the NuRD-complex to the genome regulatory elements. Therefore, the Ttk69 protein must be capable of a simultaneous interaction with the MEP1 and $\mathrm{ZnF}$ proteins. To test this assumption, we decided to localize the interacting domains of these proteins. Using appropriate deletion constructs, we found that the zinc fingers of Ttk69 are sufficient to interact with CG10321 and CG1792 (Fig. 2, a). While earlier, the Ttk region upstream of the zinc fingers was identified as interacting with MEP1 (Reddy et al., 2010). These results demonstrate that the Ttk69 protein is able to interact simultaneously with the NuRD complex and DNA-binding $\mathrm{ZnF}$ proteins. In addition, we localized interacting regions of CG10321 (see Fig. 2, b) and CG1792 (see Fig. 2, c) at the middle parts of the proteins, i. e., between the N-terminal ZAD domain and zinc fingers. So the interactions of these proteins with Ttk69 do not interfere with the DNA-binding activity of CG10321 and CG1792.

$a$

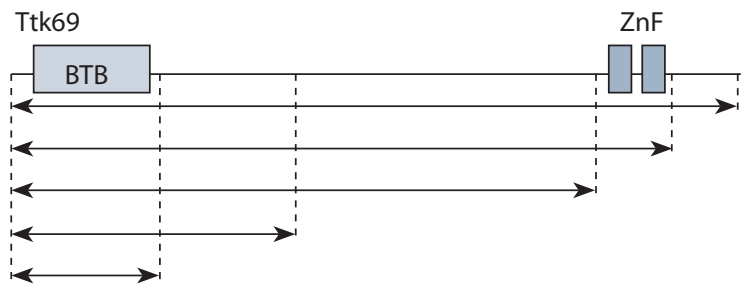

$a$

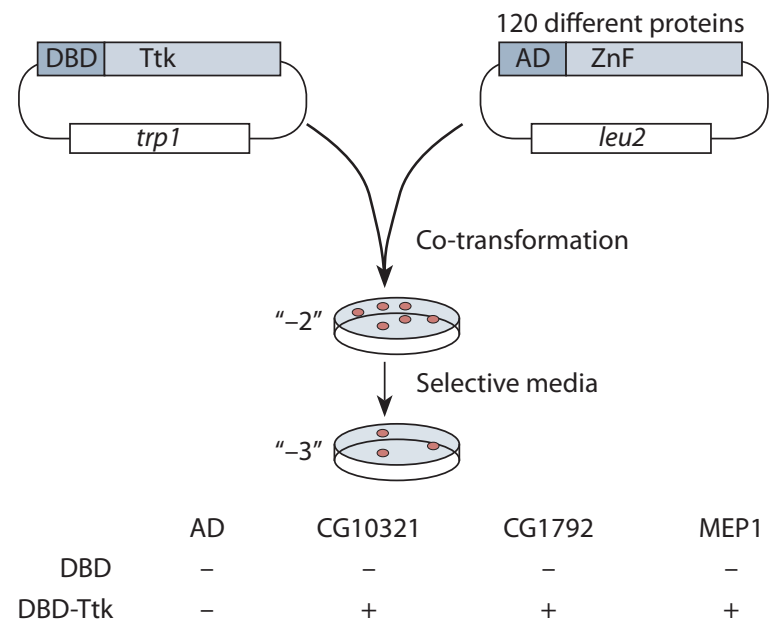

Fig. 1. Ttk is able to direct interaction with $\mathrm{ZnF}$ proteins.

$a$ - principle of the yeast two-hybrid assay $(\mathrm{Y} 2 \mathrm{H}) ; b$ - positive results of $\mathrm{Y} 2 \mathrm{H}$ screening. The results are summarized in columns, with the ' $t$ ' and ' - ' signs referring to the presence and absence of interaction, respectively.

\section{Discussion}

The structure of chromatin is related with the processes of activation or repression of gene transcription. Chromatin remodeling complexes are multi-component systems that can modulate the position of nucleosomes and insert or remove certain histone marks. One of the main complexes of this type in eukaryotes is Mi-2/NuRD. Studies have shown that Mi-2/ NuRD complexes not only move nucleosomes through ATP-

$\begin{array}{cccc} & \text { CG10321 } & \text { CG1792 } & \text { AD } \\ {[1-643]} & + & + & - \\ {[1-570]} & + & + & - \\ {[1-500]} & - & - & - \\ {[1-265]} & - & - & - \\ {[1-120]} & - & - & -\end{array}$

$b$
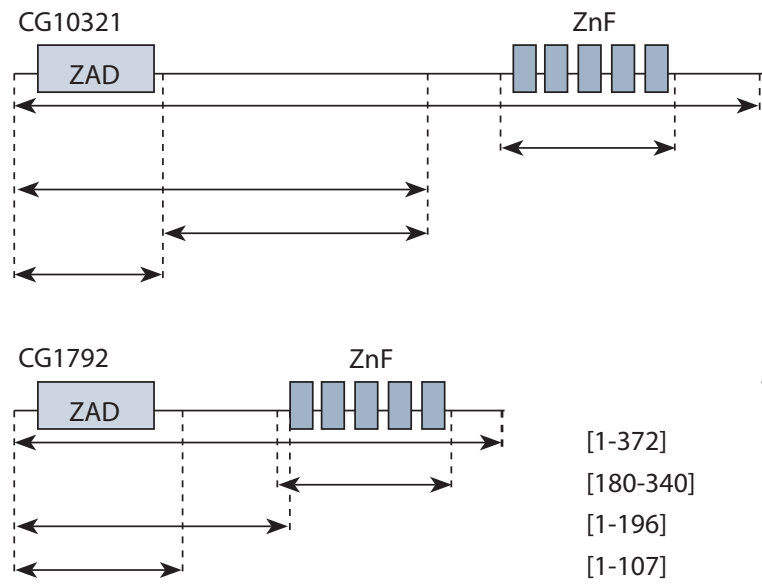

$\begin{array}{lcc} & \text { Ttk } & \text { DBD } \\ {[1-372]} & + & - \\ {[180-340]} & - & - \\ {[1-196]} & + & - \\ {[1-107]} & - & -\end{array}$

Fig. 2. Localization of interacting regions in Ttk, CG10321 and CG1792.

$a$ - localization of the Ttk region interacting with CG10321 and CG1792 in the yeast two-hybrid assay. Full-sized or fragments of Ttk were fused to the GAL4 DNAbinding domain (DBD) and tested for interaction with CG10321 and CG1792 fused to the GAL4 activating domain (AD). Ttk fusions were tested for the absence of interaction with the GAL4 activating domain alone; b, c - localization of CG10321 and CG1792 regions interacting with CLAMP in the yeast two-hybrid assay. Different fragments of these proteins were fused to the GAL4 activating domain and tested for interaction with Ttk fused to the GAL4 DNA-binding domain. 
dependent chromatin remodeling, but also contain subunits that deacetylate histones and bind methylated DNA.

In Drosophila, one of the variants of the Mi-2 complex, $\mathrm{dMec}$, was purified. A unique component of this complex is the conserved protein MEP1, which is responsible for the binding profile of the entire complex at chromatin sites. It was shown that this type of the complex is critically necessary for somatic differentiation at the stage of transition from early to late embryogenesis. Presumably, the MEP1 protein is the structure-forming component of this complex. Previously it was shown that, in particular, it binds to the transcription repressor protein Ttk69. It is possible that this repressing activity is associated with the recruitment of the NuRD complex to genomic targets. However, no specific binding motifs are known for either MEP1 or Ttk69. According to our hypothesis, MEP1 and Ttk69 form many contacts with DNA-binding proteins which ensure the specific positioning of the NuRD complex on chromatin. As part of testing such a hypothesis, we searched for protein partners of Ttk69 by screening among DNA-binding $\mathrm{ZnF}$ proteins. As a result, we found the CG10321 and CG1792 proteins, which can act as potential recruiters of the Ttk-containing complex to chromatin. We localized interaction regions of these proteins and showed that the unstructured regions of the CG10321 and CG1792 proteins interact with Ttk69's zinc fingers, while zinc fingers of CG10321 and CG1792 remain free for DNA binding. At the same time, MEP1 binds to the area adjacent to the zinc fingers in Ttk69. This result indicates the possibility of simultaneous interaction of the Ttk69 protein with MEP1 and DNA-binding $\mathrm{ZnF}$ proteins.

\section{Conclusions}

At the present time, several dozen complexes participating in epigenetic regulation of gene expression are described. Nevetheless, mechanisms of their specific recruitment to target loci are still unclear. One of the current models implies that a specific ensemble of DNA-binding proteins on a regulatory element may serve as a platform for the targeted complex assembly. Here, we report on two new earlier undescribed proteins with DNA-binding domains, which potentially can recruit the NuRD complex to its genomic loci. Further research on the aspects of its interactions with the NuRD complex can contrtibute to our better understanding of epigenetic complexes recruitment.

\section{References}

Boyle M.J., Berg C.A. Control in time and space: Tramtrack69 cooperates with Notch and Ecdysone to repress ectopic fate and shape changes during Drosophila egg chamber maturation. Development. 2009;136(24):4187-4197. DOI 10.1242/dev.042770.

Chen Y.-J., Chiang C.-S., Weng L.-C., Lengyel J.A., Liaw G.-J. Tramtrack69 is required for the early repression of tailless expression. Mech. Dev. 2002;116:75-83.
Chopra V.S., Srinivasan A., Kumar R.P., Mishra K., Basquin D., Docquier M., Seum C., Pauli D., Mishra R.K. Transcriptional activation by GAGA factor is through its direct interaction with dmTAF3. Dev. Biol. 2008;317(2):660-670.

Defossez P.A., Kelly K.F., Filion G.J., Pérez-Torrado R., Magdinier F., Menoni H., Nordgaard C.L., Daniel J.M., Gilson E. The human enhancer blocker CTC-binding factor interacts with the transcription factor Kaiso. J. Biol. Chem. 2005;280(52):43017-43023.

Kulakovskiy I.V., Makeev V.J. Discovery of DNA motifs recognized by transcription factors through integration of different experimental sources. Biophysics. 2009;54:667-674.

Lai Z.C., Li Y. Tramtrack69 is positively and autonomously required for Drosophila photoreceptor development. Genetics. 1999;152(1): 299-305.

Liaw G.J. Pits, a protein interacting with Ttk69 and Sin3A, has links to histone deacetylation. Sci. Rep. 2016;6:33388. DOI 10.1038/ srep33388.

Melnick A., Carlile G., Ahmad K.F., Kiang C.L., Corcoran C., Bardwell V., Prive G.G., Licht J.D. Critical residues within the BTB domain of PLZF and Bcl-6 modulate interaction with corepressors. Mol. Cell. Biol. 2002;22(6):1804-1818.

Murawsky C.M., Brehm A., Badenhorst P., Lowe N., Becker P.B., Travers A.A. Tramtrack69 interacts with the dMi-2 subunit of the Drosophila NuRD chromatin remodelling complex. EMBO Rep. 2001;2(12):1089-1094.

Pagans S., Piñeyro D., Kosoy A., Bernués J., Azorín F. Repression by TTK 69 of GAGA-mediated activation occurs in the absence of TTK69 binding to DNA and solely requires the contribution of the POZ/BTB domain of TTK69. J. Biol. Chem. 2004;279(11): 9725-9732.

Perez-Torrado R., Yamada D., Defossez P.A. Born to bind: the BTB protein-protein interaction domain. BioEssays. 2006;28(12):11941202.

Peters N.C., Thayer N.H., Kerr S.A., Tompa M., Berg C.A. Following the 'tracks': Tramtrack69 regulates epithelial tube expansion in the Drosophila ovary through Paxillin, Dynamin, and the homeobox protein Mirror. Dev. Biol. 2013;378(2):154-169. DOI 10.1016/j. ydbio.2013.03.017.

Pointud J.C., Larsson J., Dastugue B., Couderc J.L. The BTB/POZ domain of the regulatory proteins Bric à brac $1(\mathrm{BAB} 1)$ and Bric à brac 2 (BAB2) interacts with the novel Drosophila TAF(II) factor BIP2/dTAF(II)155. Dev. Biol. 2001;237(2):368-380.

Reddy B.A., Bajpe P.K., Bassett A., Moshkin Y.M., Kozhevnikova E., Bezstarosti K., Demmers J.A., Travers A.A., Verrijzer C.P. Drosophila transcription factor Tramtrack69 binds MEP1 to recruit the chromatin remodeler NuRD. Mol. Cell. Biol. 2010;30(21):5234-5244. DOI 10.1128/MCB.00266-10.

Stogios P.J., Downs G.S., Jauhal J.J., Nandra S.K., Privé G.G. Sequence and structural analysis of BTB domain proteins. Genome Biol. 2005;6(10):R82.

Wang C., Guo X., Dou K., Chen H., Xi R. Ttk69 acts as a master repressor of enteroendocrine cell specification in Drosophila intestinal stem cell lineages. Development. 2015;142(19):3321-3331. DOI 10.1242/dev.123208.

Wen Y., Nguyen D., Li Y., Lai Z.C. The N-terminal BTB/POZ domain and C-terminal sequences are essential for Tramtrack69 to specify cell fate in the developing Drosophila eye. Genetics. 2000;156(1): 195-203.

Acknowledgements. This study was supported by the Russian Foundation for Basic Research (project No. 18-04-01272). The work was performed using the equipment of the IGB RAS facilities supported by the Ministry of Science and Education of the Russian Federation.

Conflict of interest. The authors declare no conflict of interest.

Received November 22, 2018. Revised December 11, 2018. Accepted December 11, 2018. 